\title{
TREE SHAPE AND FORM IN ANCIENT COPPICE WOODLANDS
}

\author{
PETR MADĚRA*, TOMÁŠ SLACH, LUBOŠ ÚRADNÍČEK, JAN LACINA, \\ LINDA ČERNUŠÁKOVÁ, MICHAL FRIEDL, RADOMÍR ŘEPKA, ANTONÍN BUČEK
}

Department of Forest Botany, Dendrology and Geobiocoenology, Faculty of Forestry and Wood Technology, Mendel University in Brno, Zemědělská 3, 613 00, Czech Republic, *Corresponding author, e-mail: petrmad@mendelu.cz

Received: $13^{\text {th }}$ January 2017 , Accepted: $19^{\text {th }}$ April 2017

\begin{abstract}
Ancient coppice woodlands are coppice-originated forest stands with a long-term continual development, and with the preserved typical natural and historic elements of old sprout forests. Prominent natural elements in the ancient coppice woodlands are namely old coppice stools. There is, in scientific literature, lack of information about features of ancient coppice stools. Therefore, our contribution aims to describe shape and form of ancient coppice stools, including the most important microhabitat of coppice woodlands - dendrothelms. Based on field survey of 20 localities of important coppice woodlands we recorded 135 ancient coppice stools of 13 tree species and a total of 80 dendrothelms in 9 tree species. Basic features of ancient coppice stools and dendrothlems were measured and evaluated.
\end{abstract}

Keywords: coppice stools, dendrothelm, dendrotelm, stool head, worked tree, tree microhabitat, dendromicrohabitat

\section{INTRODUCTION}

Traditional cultural landscapes (Cullotta \& Barbera, 2011) or ancient countrysides (Clare $\&$ Bunce, 2006) are landscapes that reflect human-nature interactions over time. Those landscapes have been created by long-term application of traditional landuse techniques, coppicing and pollarding in forestry belongs among them. Coppicing (Stajic at al., 2009; Szabo, 2009; Sjölund \& Jump, 2013, Müllerová et al., 2014; Szabó et al., 2015) and pollarding (Rozas, 2004; Read, 2006; Cousins \& Duval, 2012; Mitchell, 1989) were widespread in Europe until the beginning of the $20^{\text {th }}$ century (Szabó et al., 2015). Dendroarchaeological research showed that coppicing started in the Neolithic, and was practiced throughout the European history (Szabo, 2009). Brown \& Oosterhuist (1981) rightfully used the term 'ancient coppice woods' for the forest that has been continuously coppiced more than two centuries (Mölder et al., 2015). First written records about coppicing come from 1384 (Bretholz, 1930) and about pollarding from 1523 (Fitzherbert in Read, 2000).

The conversion of coppice woodlands into high forests started before the $19^{\text {th }}$ century. Already in the $17^{\text {th }}$ century, the practice of singling out coppice stools (cutting out all shoots except for the strongest and most upright growing ones) resulting in structures similar to 
Maděra, P., Slach, T., Úradníček, L., Lacina, J., Černušáková, L., Friedl, M., Řepka, R., Buček, A.: Tree shape and form in ancient coppice woodlands

high forests that are called pseudo high forests or stored forests was recorded in management instructions (Müllerová et al., 2014). Czech Republic currently belongs to countries with a very low proportion of coppice woods. More than $1000 \mathrm{~km}^{2}$ of coppice woods were converted into high and stored forests after World War II. These stored forests could be the last remainders of ancient coppice woods. The area and distribution of stored forests are not known in the Czech Republic because stored forests are registered as high forests in forest management plans (Maděra et al., 2016). Similarly, less than $1 \%$ of coppice woodlands and coppices with standards are reported from Cyprus, UK, Denmark, Sweden, Poland, Germany, Ireland, Finland, Malta, Estonia, Latvia and Lithuania. On the other hand, more than $10 \%$ of these woodlands occur in Greece, Italy, France, Bulgaria, Hungary, Spain, Portugal, Luxembourg, Belgium and Slovenia (Kadavý et al., 2011).

Important components of ancient coppice woodlands are ancient coppice stools, multi-stemmed trees whose massive bases result from the centuries of felling and regrowth (Rackham, 2008). Glaves et al. (2009a; 2009b) added that the ancient woodlands typically feature a diverse range of tree forms. These are often the product of various types of human interference and management. The authors call the trees modified by human management as 'worked' or 'working' trees, which include pollards (lapsed and managed), coppices (including stored stems), coppards, shredded trees, stubs, multi-trunks, medusoids and layered trees (Read, 2000). These tree forms occur not only in the coppice woodlands, but outside woodlands too (Brown \& Fisher, 2009) as solitary veteran trees, memorable trees, boundary trees, in wood pastures, wood lots, alleys and as other small woody elements in the landscape.

Typical of large and old living trees are high volumes of coarse woody debris at different stages of decomposition and many types of tree microhabitats. Winter \& Möller (2008), Remm \& Lõhmus (2011), Vuidot et al. (2011), Larrieu et al. (2012), Regnery et al. (2013a; 2013b), Larrieu et al. (2014), Ouin et al. (2015) and Kraus et al. (2016) distinguish many types of tree microhabitats - different types of stem cavities, branch holes, bark losses, exposed sapwood and heartwood, trunk and crown breakages, cracks and scars, bark pockets, bark structures, crown deadwood, root buttress, witches brooms, cankers and burrs, fruiting bodies of fungi, epiphytes, nests, sap and resin runs, that are very valuable from the forest biodiversity point of view, because they serve as habitats for birds, bats, insects, small mammals, micro crustaceans, amphibians, fungi, lichens, mosses, etc. Tree microhabitats are commonly found in forest stands that have surpassed the first half of their natural life cycle. In regularly managed forests that are usually harvested no later than after the first third of the natural cycle, these features are often very rare (Cateau et al., 2015). On the other hand, certain types of microhabitats such as dendrothelms (water filled tree holes) may be more abundant in managed forests due to harvesting activities (Vuidot et al., 2011; Larrieu et al., 2012).

Most works on tree microhabitats focus fir-beech forests and compare old growth, mature forests with managed forests (Schmidl et al., 2008; Winter \& Möller, 2008; Remm \& Lõhmus, 2011; Vuidot et al., 2011; Larrieau et al., 2012; Larrieau et al., 2014). Subject of interest in these studies are animals living in tree microhabitats, quantity of tree microhabitats in different forest types and age classes.

Dendrothelms are favoured by coppicing because their development is based on the removal of stems from the live coppice stools. Kitching (1971) considers water-filled tree holes to be the most common type of phytothelms in the temperate zone, distinguishing "pans", which maintain unbroken bark lining throughout their existence and "rot-holes", which penetrate to the tree sapwood and heartwood. He connects the "rot-holes" type of dendrothelms with stump-holes, holes in pollarded or coppiced trees and holes originating in 
wood exposed to pruning. Ouin et al., (2015) recorded dendrothelms when the orifice was wider than $3 \mathrm{~cm}$, differentiating similarly between rotted-bottom dendrothelms with the cavity bottom of decayed wood and bark-lined dendrothelms with the cavity bottom of intact bark.

The first classification of dendrothelms was published by Kitching (1971) and it was based on their position on the stem (canopy layer above and field layer below $2 \mathrm{~m}$ above ground) and on their size (small - diameter up to $15 \mathrm{~cm}$, medium - diameter $15-30 \mathrm{~cm}$, and large diameter over $30 \mathrm{~cm}$ ). Schmidl et al. (2008) pointed out the importance of leaf litter content and water volume in dendrothelms. They recorded water-holding capacities ranging from 0.2 to 131 and maximum depths from 5 to $57 \mathrm{~cm}$. Total litter contents (dry material) were 745 $\mathrm{g}$ in large dendrothelms and only $0.1 \mathrm{~g}$ in very small dendrothelms. Kitching (2000) mentioned dendrothelms with water volumes greater than 20 or 30 litres.

Dendrothelms become filled with rainwater either directly, when nutrients are transferred from the foliage of the above canopy, or indirectly by stem-flow water (Schmidl et al., 2008). The chemical content of the stem-flow water is influenced by the nature of the bark itself (Carpenter, 1982) as well as by dry atmospheric depositions on the bark (Paradise \& Dunson, 1997). Leaf litter is the main source of energy entering dendrothelm systems and its quality varies across the tree species (Fish \& Carpenter, 1982; Carpenter, 1983). Cadavers, principally of arthropods, provide an additional supply of nutrients for the saprophagous fauna within the dendrothelms (Yee \& Juliano, 2006).

Dendrothelm-dwelling invertebrate species are not numerous, but very specialized: there are only 14 species in Europe with only six of them specifically associated with dendrotelms (Kitching, 1971). Large tree-hole volume does not necessarily result in higher numbers of species, but does tend to support more individuals (Schmidl et al., 2008).

Most of the dendrothelms sampled by Schmidl et al., (2008) were in beech trees (Fagus sylvatica), a few dendrothelms were examined in hornbeam (Carpinus betulus), ash (Fraxinus excelsior), maple (Acer pseudoplatanus), oak (Quercus rubra) and alder (Alnus glutinosa). In Germany, Röhnert (1950) recorded dendrothelms in Quercus robur, Fraxinus excelsior, Ulmus laevis, U.glabra, Tilia cordata, T.platyphyllos, Alnus glutinosa, Fagus sylvatica, Carpinus betulus, Acer plantanoides, A.campestre, Aesculus hippocastanum, Betula pendula, Abies alba and Picea abies. Fir forms dendrothelms very scarcely (Larrieau, 2012) while in beech they were recorded more often (Kitching, 1971; Larrieau, 2012). Larrieau (2012) counted 8-54 dendrothelms per hectare in different types of beech-fir forests; in unmanaged stands, dendrothelms were present in only $10 \%$ of microhabitat-bearing trees and were more abundant in managed stands combining high intensity of logging with the predominance of beech. The result suggests that this microhabitat is quite rare in natural mixed forests while being very frequent in artificial beech forests.

There is a lack of knowledge about qualitative signs of microhabitats, for example their size, or relationship between species and microhabitat types neither has been anybody ever interested in a basic description of ancient coppice stools in ancient coppice woodlands. Published were only general characterizations of working trees, e.g. by Read (2000).

The aim of work is to emphasize the importance of ancient coppice woodlands for maintaining cultural and natural heritage, on example of the description of shape and form of ancient coppice stools in some areas of the Czech Republic. 
Maděra, P., Slach, T., Úradníček, L., Lacina, J., Černušáková, L., Friedl, M., Řepka, R., Buček, A.: Tree shape and form in ancient coppice woodlands

\section{MATERIAL AND METHODS}

Ancient coppice woodlands are coppice-originated forest stands with a long-term continual development, and with the preserved typical natural and historic elements of old sprout forests. Prominent natural elements in the ancient coppice woodlands are namely old coppice stools, pollard trees, reserved trees, dendrothelms, nesting trees, ecotone communities of forest margins, forest openings, and important plant and animal species. The ancient coppice stool is a multi-stem tree of coppice origin, where the original stump is no more visible and the stools are structured in a circle or in an ellipse of large diameter.

We searched for the presence of ancient coppice stools and dendrothelms (two most typical features of ancient coppice woodlands) during the preliminary inventory of ancient coppice woods in selected areas of the Czech Republic and we collected data from the following localities of ancient coppice woodlands:

Moravsko-krumlovský les (49.03094N, 16.35846E), Bohutický les (48.99673N, 16.31410E), Pustina u Kadova (48.97319N, 16.29059E), Nesovice (49.13895N, 17.08502E), Hvozdec - Želešický háj (49.1093N, 16.5835E), Střelický les (49.1367N, 16.5165E), Přední kout (48.9763N, 16.7670E), Pekárna (49.2094N, 16.5097E), Hodonínská dúbrava (48.88927N, 17.09064E), Drahonín (49.42049 N, 16.27431 E), Synalov (49.42698 N, 16.42510 E), Křeptov (49.44835 N, 16.36843 E), Květnice (49.35298 N, 16.42020 E), Svídovec (49.38153 N, 16.46720 E), Lesoňovice (49.51883 N, 16.29954 E), Smrček (49.45813 N, 16.29272 E), Býšovec (49.47634 N, 16.28181 E), Nad Hlubokým (49.57845 N, 16.30089 E) and Blatiny (49.64717 N, 16.08792 E). All localities belong to stored forests of coppice origin. For a comparison, we added one locality from Romania in the Banat Mts., where Czech villages established by Maria Theresa in 1820 still exist, whose inhabitants actively coppiced the surroundings forests (Maděra et al., 2014).

In each locality, we recorded up to 10 biggest ancient coppice stools, by which we estimated the species, counted the number of stems and measured the girth of the whole stool near the ground.

Dendrothelms were recorded randomly from all trees in the locality. We measured and recorded the following characteristics: presence of water, depth of water, depth of litter, orifice size (length, width and depth), vertical position (basal, stem and crown, by the basal position we distinguished the position among stools, among root buttresses and in stump), horizontal position (central and lateral), and position of orifice (horizontal, vertical and inclined). Subsequently, the orifice area (as area of ellipse) and cavity volume (as elliptic cylinder) were calculated.

The similarity of localities with the highest occurrence of oak ancient coppice stools was tested by ANOVA.

\section{RESULTS}

\section{Ancient coppice stools}

We recorded 135 ancient coppice stools of 13 tree species (Tab. 1). Species most abundant in the Czech localities were Quercus petraea (33.6\%), Quercus robur (29.0\%), Fagus sylvatica (8.4\%) and Carpinus betulus (8.4\%). In Banat, most abundant species were Fagus sylvatica (42.9\%), Carpinus betulus (39.2\%) and Acer campestre (17.9\%).

As to parameters measured in ancient polycormons (ancient coppice stools), the largest circumference (Tab. 2, Fig. 1) was found in a pedunculate oak (Quercus robur) - $1446 \mathrm{~cm}$; another tree with the circumference over nine metres was hornbeam (Carpinus betulus). The 
highest number of coppice stems shooting from one individual of ancient coppice polycormon (Tab. 2, Fig. 2) totalled 42 in beech (Fagus sylvatica) and 31 in hornbeam (C.betulus) on the actively coppiced site in Banat. In over-aged coppices (stored coppice woods) on the Czech sites, the highest number of stems was recorded in elm (Ulmus glabra) - 17, lime (Tilia cordata) - 11, and oak (Quercus petraea) - 10.

Table 1: Species composition of ancient coppice stools in Czech localities and Banat Mts.

\begin{tabular}{|c|c|c|c|c|}
\hline & \multicolumn{2}{|c|}{ Czech localities } & \multicolumn{2}{c|}{ Banat Mts. } \\
\hline & No of stools & $\%$ & No of stools & $\%$ \\
\hline Acer campestre & 8 & 7.5 & 5 & 17.9 \\
\hline Acer platanoides & 2 & 1.9 & & \\
\hline Acer pseudoplatanus & 3 & 2.8 & & \\
\hline Carpinus betulus & 9 & 8.4 & 11 & 39.2 \\
\hline Fagus sylvatica & 8 & 7.5 & 12 & 42.9 \\
\hline Quercus petraea & 36 & 33.6 & & \\
\hline Quercus pubescens & 1 & 0.9 & & \\
\hline Quercus robur & 31 & 29.0 & & \\
\hline Robinia pseudacacia & 1 & 0.9 & & \\
\hline Sorbus torminalis & 1 & 1,149425 & & \\
\hline Tilia cordata & 5 & 4.7 & & \\
\hline Ulmus glabra & 1 & 0.9 & & \\
\hline Ulmus laevis & 1 & 0.9 & & \\
\hline
\end{tabular}

Table 2: The largest recorded stool circumference and the number of stems in stool according to the tree species

\begin{tabular}{|c|c|c|}
\hline & Stool girth $[\mathrm{cm}]$ & No. of stems \\
\hline Acer campestre & 454 & 7 \\
\hline Acer platanoides & 275 & 8 \\
\hline Acer pseudoplatanus & 750 & 8 \\
\hline Carpinus betulus & 980 & 31 \\
\hline Fagus sylvatica & 785 & 42 \\
\hline Quercus petraea & 850 & 10 \\
\hline Quercus pubescens & 243 & 6 \\
\hline Quercus robur & 1446 & 7 \\
\hline Robinia pseudacacia & 337 & 2 \\
\hline Sorbus torminalis & 72 & 2 \\
\hline Tilia cordata & 857 & 11 \\
\hline Ulmus glabra & 790 & 17 \\
\hline Ulmus laevis & 569 & \\
\hline
\end{tabular}


Maděra, P., Slach, T., Úradníček, L., Lacina, J., Černušáková, L., Friedl, M., Řepka, R., Buček, A.: Tree shape and form in ancient coppice woodlands

Fig. 1: Variability of coppice stems numbers per one ancient polycormon by tree species

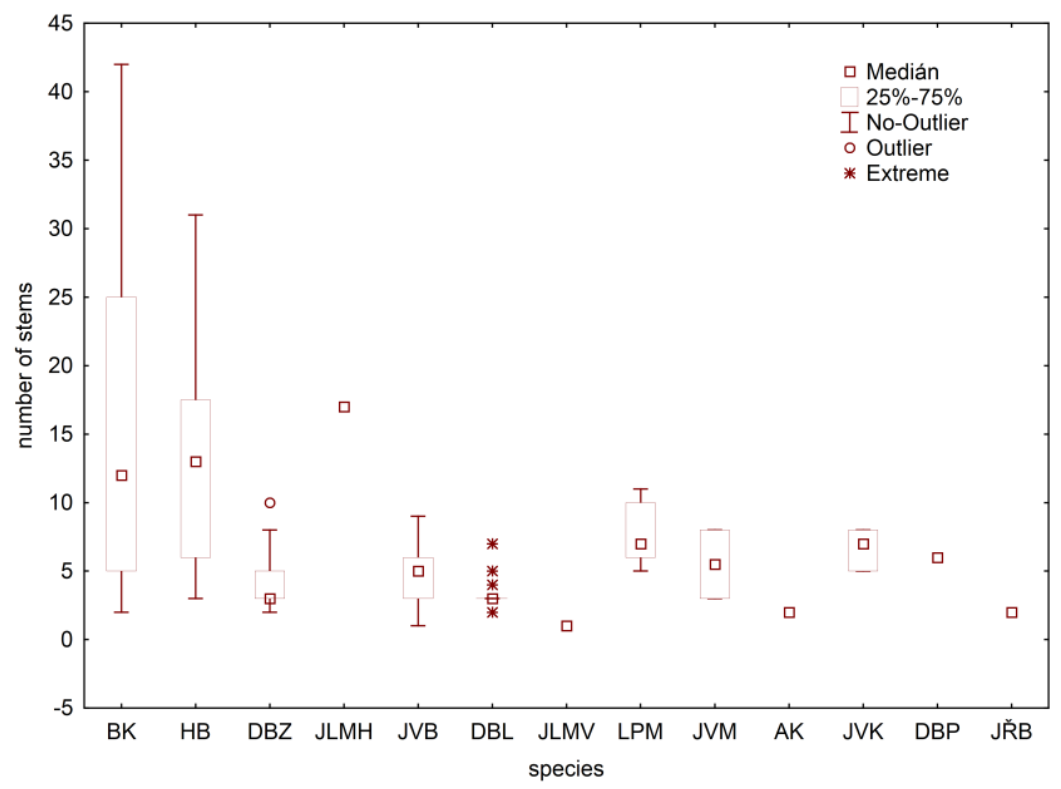

Fig. 2: Variability of ancient polycormon girths measured at ground by tree species

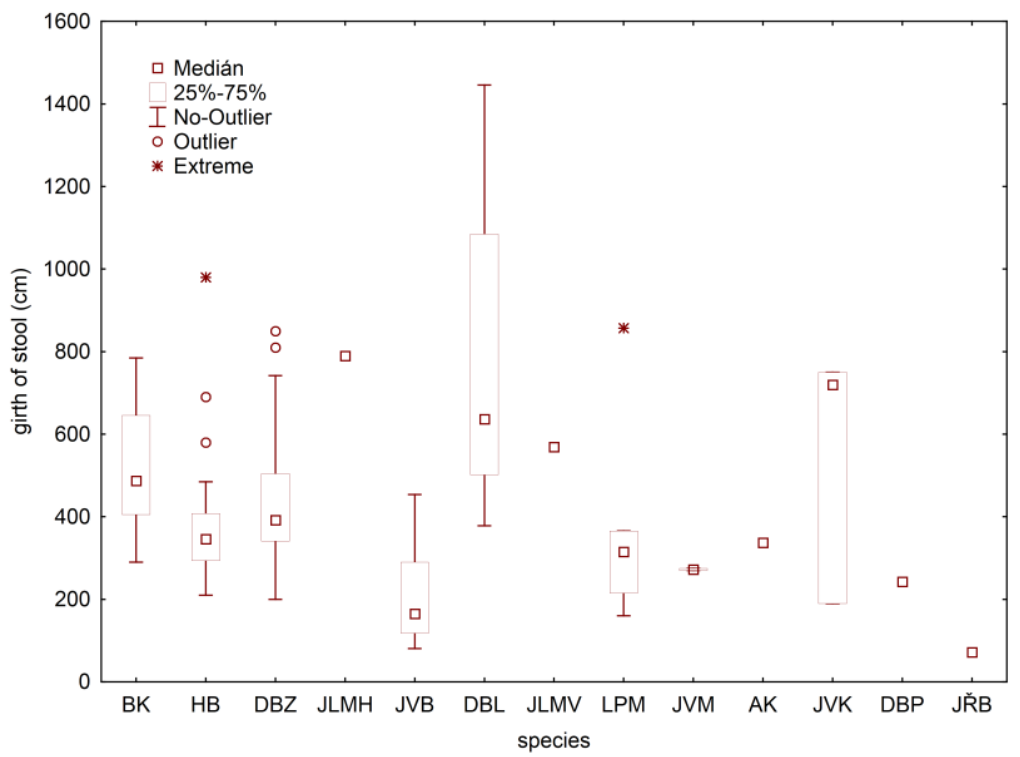

Legend (Fig. 1 and 2): BK beech, HB hornbeam, DBZ sessile oak, JLMH Scotch elm, JVB field maple, DBL pedunculate oak, JLMV European white elm, LPM small-leaved linden, JVM Norway maple, AK black locust, JVK sycamore maple, DBP pubescent oak, JǨB wild service tree 
Sometimes, the ancient polycormons create "stool heads", which are swollen stem bases coming to existence through vigorous development of callus following the repeated cut back of coppice shoots (Fig. 3). Well-developed stool heads are a distinctive and very impressive feature of some ancient polycormons (Fig. 4).

Fig. 3: The stem cross-section of small-leaved linden (Tilia cordata) shows callus vigorously growing after stem injury, which started to create a stool head.

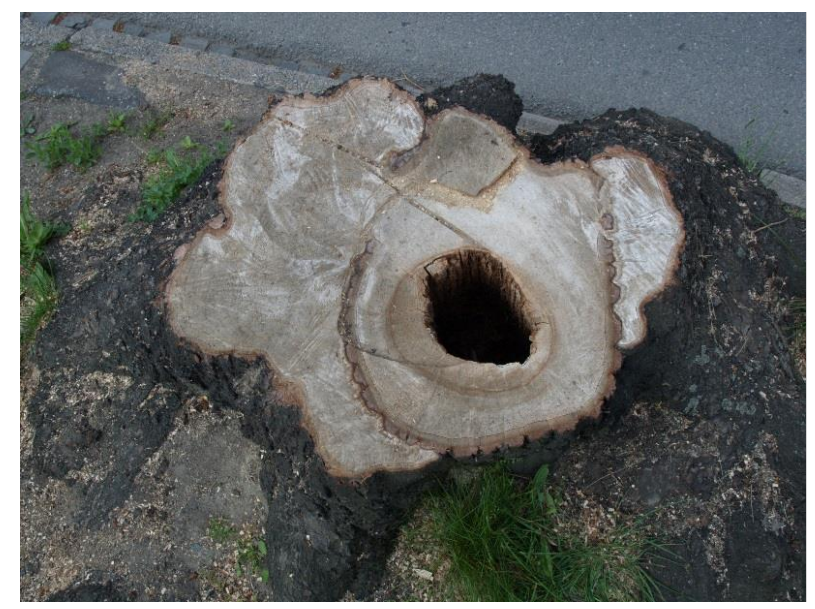

Fig. 4: A well-developed stool head of pedunculate oak (Quercus robur)

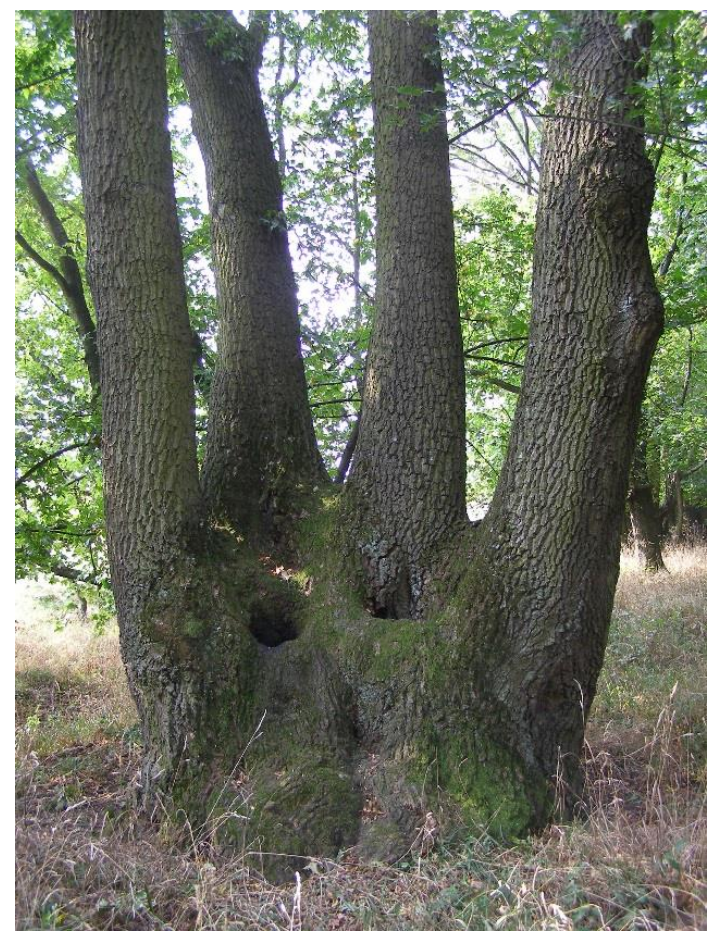


Maděra, P., Slach, T., Úradníček, L., Lacina, J., Černušáková, L., Friedl, M., Řepka, R., Buček, A.: Tree shape and form in ancient coppice woodlands

Comparing the girths of ancient coppice polycormons and the numbers of coppice stems by the sites, we can see that the Hodonínská Dúbrava (in girth of ancient coppice stools) and Banat (in number of coppice stems) localities statistically significantly differ from other sites in the Czech Republic. Clearly, although not statistically significantly, differ from the remaining Czech localities in the polycormon girth also the sites of Lesonický les Forest and Pustina u Kadova (Figs. 5 and 6).

Fig. 5: Comparison of the similarity of the girth of ancient coppice polycormons on selected sites

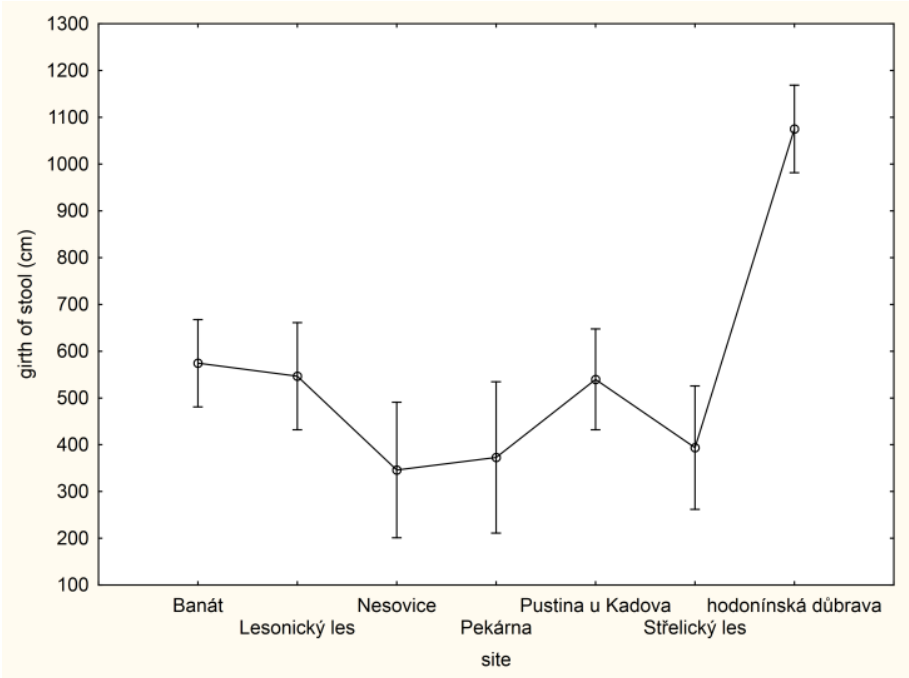

Fig. 6: Comparison of the similarity of the number of coppice stems in ancient coppice polycormons on selected sites

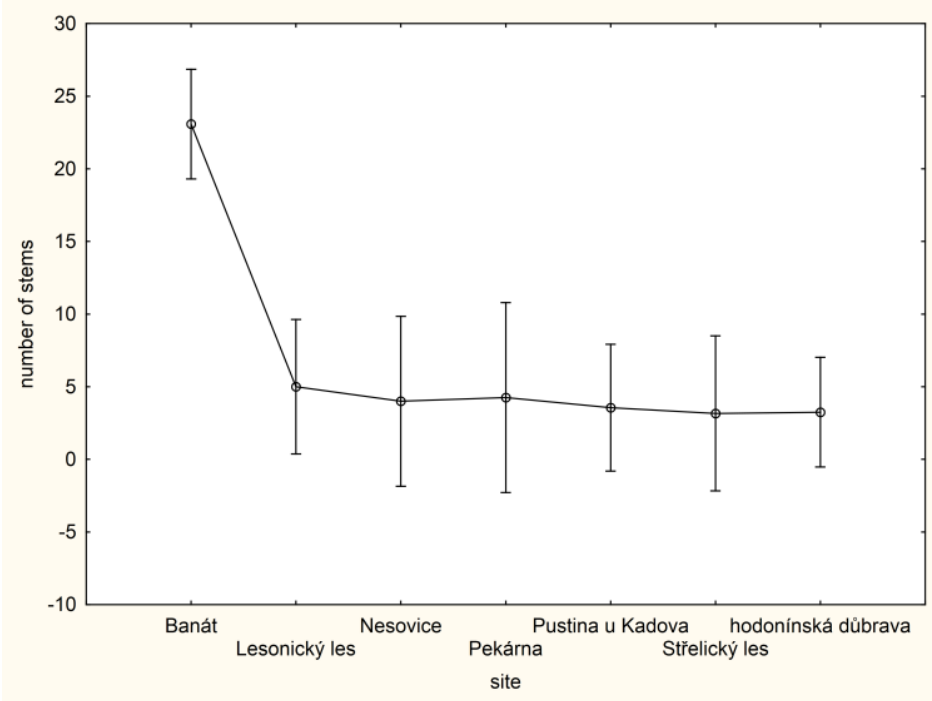




\section{Dendrothelms}

We recorded a total of 80 dendrothelms in nine tree species. Most of them were found on the polycormons of Quercus petraea (64\%), which were followed by Quercus robur $(10 \%)$, Acer campestre (9\%) and Carpinus betulus (8\%). Other tree species (Fagus sylvatica, Quercus cerris, Acer pseudoplatanus, Acer platanoides, Tilia cordata) exhibited only single occurrences.

As to the size of dendrothelms (Tab. 3), we can state that the smallest ones are most abundant while the abundance of dendrothelms decreases with their increasing size. Orifice size was most frequently up to $100 \mathrm{~cm}^{2}$ with the largest one of $5220 \mathrm{~cm}^{2}$ being observed in beech. Cavity depth most often ranged from 10 to $20 \mathrm{~cm}$ with a maximum of $75 \mathrm{~cm}$ in Turkey oak. The most frequently occurring cavity volume was calculated as up to 51 with the largest one of 261 litres being recorded in beech.

More than half of dendrothelms contained water only temporarily, which dried up during the year; $58 \%$ of dendrothelms did not contain water at the time of survey. In water-containing dendrothelms, the most frequently observed level depth was up to $10 \mathrm{~cm}$ with the deepest water level recorded at $33 \mathrm{~cm}$. No litter was found in $64 \%$ of dendrothelms and if some litter occurred, it was most often up to a depth of $10 \mathrm{~cm}, 33 \mathrm{~cm}$ at the most.

As to the typification of dendrothelms, $81 \%$ of them are located on the polycormon base and only $19 \%$ are located on the stem. No dendrothelms were observed in the crown. Basal dendrothelms were mostly of stump origin (54\%), $40 \%$ of them were located in the middle between the polycormon stems, and only $6 \%$ of dendrothelms occurred between buttresses. $64 \%$ of dendrothelms were lateral and $36 \%$ were central. More than a half of dendrothelms (55\%) exhibited horizontally positioned orifice, which indicates they are open and replenished with atmospheric water. Only $15 \%$ of dendrothelms showed vertically positioned orifice and are replenished only by water flowing down the stem. Inclined orifice was recorded in $30 \%$ of dendrothelms, which can be thus at least partly replenished also by precipitation water.

Table 3: Frequency of the occurrence of individual dendrothelm features

\begin{tabular}{|c|c|c|c|c|c|c|c|c|c|}
\hline \multicolumn{2}{|c|}{ Orifice area $\left[\mathrm{cm}^{2}\right]$} & \multicolumn{2}{c|}{ Cavity depth $[\mathrm{cm}]$} & \multicolumn{2}{c|}{ Water depth $[\mathrm{cm}]$} & \multicolumn{2}{c|}{ Litter depth [cm] } & \multicolumn{2}{c|}{ Cavity volume [1] } \\
\hline $1-100$ & 25 & $1-10$ & 10 & 0 & 46 & 0 & 51 & $0-1$ & 18 \\
\hline $101-200$ & 13 & $11-20$ & 24 & $1-10$ & 18 & $1-10$ & 14 & $1,1-5$ & 27 \\
\hline $201-300$ & 13 & $21-30$ & 19 & $11-20$ & 12 & $11-20$ & 10 & $5,1-10$ & 11 \\
\hline $301-400$ & 4 & $31-40$ & 15 & $21-30$ & 2 & $21-30$ & 2 & $10,1-20$ & 9 \\
\hline $401-500$ & 5 & $41-50$ & 6 & $31-40$ & 2 & $31-40$ & 2 & $20,1-50$ & 8 \\
\hline $501-1000$ & 10 & $51-60$ & 3 & & & & & $50,1-100$ & 5 \\
\hline $1001-2000$ & 8 & $61-70$ & 2 & & & & & $100,1-200$ & 0 \\
\hline $2001-3000$ & 0 & $71-80$ & 1 & & & & & $200,1-300$ & 1 \\
\hline $3001-4000$ & 1 & & & & & & & & \\
\hline $4001-5000$ & 0 & & & & & & & & \\
\hline $5001-6000$ & 1 & & & & & & & & \\
\hline
\end{tabular}


Maděra, P., Slach, T., Úradníček, L., Lacina, J., Černušáková, L., Friedl, M., Řepka, R., Buček, A.: Tree shape and form in ancient coppice woodlands

\section{DISCUSSION}

The forms of "worked" or "working trees" were defined by Read (2000). However, in scientific literature, quantitative information about the shape of such tree forms, especially coppice stools, is missing. Ancient coppice stools are the most important feature of ancient coppice woodlands and they deserve increased attention. Vrška et. al., (2016) distinguished circular, compact and oblong or jagged shape according to the projection of individual buffers around the stools. They surveyed the number of stems in oak (Quercus petraea) polycormons simultaneously on two sites of ancient coppice wood - Lipina and Šobes (Podyjí NP, Czech Republic). Only $25 \%$ of trees were single-stemmed; two-, three- and four-stemmed stools predominated and the highest number of stems in the stool was 14 . Nevertheless, as shown by our results from the Romanian Banat, polycormons in long-term and actively managed coppices can exhibit up to multiples of stem numbers, by which they can be easily distinguished from stored coppice forests.

As one of the largest polycormons found in the above surveyed sites, Vrška et al., (2016) mention a seven-stemmed polycormon of oak (Quercus petraea) with a diameter at the base of nearly 5 metres. Thus, they recorded somewhat higher numbers and larger sizes than were our research results in oak. Nevertheless, the largest diameters of ancient coppice polycormons mentioned in scientific literature are those published by Piggot (1989) for small-leaved linden (Tilia cordata) - 6-8 m, occurring on many sites in north Lancashire and in the Lake District, UK.

It seems that antiquity of localities with coppice woodlands can be quickly determined and mutually compared exactly according to the size of several largest polycormons. Polycormon girth at the base, or in other words, the diameter of imaginary circle formed by individual stems of the polycormon, is directly proportional to age during which it was coppiced (Piggot, 1989; Vrška et al., 2016). This corresponds to our results when we recorded significant differences between individual sites; from this point of view, the sites surveyed by Vrška et al., (2016) in the Podyjí National Park are even more ancient.

Age of ancient polycormons can be determined only with difficulties and can be only estimated. Piggot (1989) published the first method for estimating the age of coppice polycormons, which was based on extrapolation between the growth of polycormons of limes (Tilia cordata) and maiden trees. By comparing the growth of lime sprouts of known-age, he determined the diameter of circular polycormon at the base to be by 1.8 times larger than the diameter of maiden tree stem of the same age at breast height. This is how he estimated the age of the bulkiest lime polycormons by comparing them with the maiden trees of diameter at breast height by 1.8 smaller to be 1300 - 1900 years. Rackham (1986) described ancient European ash (Fraxinus excelsior) coppice stools, which were found to be thousands of years old. Vrška et al., (2016) published their own method of age estimation and mentioned the polycormon of oak (Quercus petraea) with 7 stems and stool diameter at ground up to $5 \mathrm{~m}$, which was $825 \pm 145$ (SE) years old. It seems however that these estimates may be somewhat overstated. Coppice polycormons of beech with the diameter of $2.5 \mathrm{~m}$ observed in Banat are most likely older than 200 years because the area was colonized as late as in 1820 (Maděra et al., 2014).

Similarly valued can be the good condition of the sites of ancient coppice woodlands according to the representation of multi-stemmed polycormonons. Vrška et al., (2016) mentions the representation of multi-stemmed polycormons on the surveyed localities with very well preserved ancient coppice woods at $75 \%$. The more single-stemmed individuals is in the stand, which came to existence through the thinning of the original polycormons, the less representative and preserved is the site. 
The key question is whether the ancient coppice stool can be rejuvenated, i.e. whether it can become overgrown with sprouts again if the polycormon-creating stems would be cut down. Rackham (2003) noted the commonly held belief that coppice stools would not sprout if they were last cut more than 40 years ago. It should be a handicap for the restoration of coppicing in ancient coppice woodlands. Matula et al. (2012) disapprove with this argument because they observed the re-sprouting ability in oak (Quercus petraea), lime (Tilia cordata) and hornbeam (Carpinus betulus) at 61,1\%, $100 \%$ and $93.8 \%$, respectively in trees old 90 years. Kuličková (2016) recorded similar values in 110-year-old oaks. Results of Pyttel et al., (2013) indicate that the re-sprouting ability of 80-100 year old oak trees originating from the former coppice management is still high and little influenced by harvesting methods. Thus, it seems that the management of ancient coppice woodlands and ancient coppice stools, respectively, could be based on their active re-coppicing.

Field research studies indicate that dendrothelms represent a tree microhabitat type intrinsically linked with the coppice system of management. Their development starts most frequently after extraction of stem from the polycormon, which is documented by $54 \%$ of stump-originated dendrothelms. Development of receptacle between polycormon stems is another quite frequent mode $(40 \%)$. Many works deals with dendrothelms as habitats for various kinds of organisms (a list of ca. 30 works was published by Kitching (2000), but only a few studies are focused on the proper description, characteristics and occurrence of dendrothelms (Kitching, 1971; Kitching, 2000; Schmiedl et al., 2008; Larrieu et al., 2012). No detailed study was however found in scientific literature that would tackle the occurrence of dendrothelms in coppice-originated forests. Coppice woods are clearly dominated by dendrothelms occurring up to 1 metre above ground while according to Kitching (2000), it was only about $50 \%$ in the beech forest Wytham Woods near Oxford. Kitching (2000) also describes the occurrence of individual dendrothelm types and estimates 1.1 dendrothelm per hectare. Larrieau (2012) counted 8 to 54 dendrothelms per hectare in different types of beech-fir forests, dendrothelms were present in unmanaged stands in only $10 \%$ of microhabitat-bearing trees and were more numerous in managed stands, which combine high logging intensity with the predominance of beech. This result suggests that the microhabitat is quite rare in natural mixed forests, while it is occurring very frequently in artificial beech forests.

\section{CONCLUSION}

The ancient coppice stools need more precise investigation focused on their age, sprouting capacity of individual tree species at different age under different light and site conditions based on not only descriptive but also statistically designed research.

The importance of ancient coppice woodlands for the occurrence of dendrothelms as "natural microcosms" (Schmidl et al., 2008) was described and new questions were raised. Two papers published (Schmidl et al., 2008; Larrieu et al., 2012) are focused on the comparison of the occurrence of dendrothelms in unmanaged and managed stands. Their results clearly indicated higher abundance of this microhabitat type in managed forests but did not investigate coppice woodlands. According to our preliminary descriptive findings, coppicing is the most important forestry technique that supports the development of dendrothelms. 
Maděra, P., Slach, T., Úradníček, L., Lacina, J., Černušáková, L., Friedl, M., Řepka, R., Buček, A.: Tree shape and form in ancient coppice woodlands

\section{ACKNOWLEDGEMENT}

The paper is a product of the project "Ancient coppice woodlands and their significance and sustainability in the cultural landscape" supported by the Ministry of Culture of the Czech Republic (identification code DF13P01OVV015).

\section{REFERENCES}

Bretholz, B. ed., (1930). Das Urbar der Liechtensteinischen Herrschaften Nikolsburg, Durnholz, Lundenburg, Falkenstein, Feldsberg, Rabensburg, Mistelbach, Hagenberg und Gnadendorf aus dem Jahre 1414. Anstalt für Sudetendeutsche Heimatforschung, Reichenberg und Komotau.

Brown, A.H.F., Oosterhuist, L., (1981). The role of buried seed in coppice woods. Biological Conservation, 21 (1): 19-38.

Brown, N., Fisher, R., (2009). Trees outside woodlands. A report to the Woodlands Trust. 30 pp.

Carpenter, S.R., (1982). Stemflow chemistry: effects on population dynamics of detritivorous mosquitoes in tree-hole ecosystems. Oecologia, 53: 1-6.

Carpenter, S. R., (1983). Resource limitation of larval tree hole mosquitoes subsisting on beech detritus. Ecology, 64: 219-22.

Cateau, E., Larrieu, L., Vallauri, D., Savoie, J.M., Touroult, J., Brustel, H., (2015). Ancientness and maturity: Two complementary qualities of forest ecosystems. Comptes Rendus Biologies, 338: 58-73.

Clare, T., Bunce, R.G.H., (2006). The potential for using trees to help define historic landscape zones: a case study in the English Lake District. Landscape and Urban Planning, 74: 34-45.

Cousins, S.J.M., Duval, A.E., (2012). Management approaches for protected areas of cultural and biological significance: The beech pollards of Aiako Harria Natural Park. In: DuVal A, Muruetagoiena T, Ashton MS Multiple-use management of protected natural areas: Integrating conservation, restoration and recreation in the Spanish Basque Country. (pp 127-153), Yale University, New Haven, CT, United States,.

Cullotta, S., Barbera, G., (2011). Mapping traditional cultural landscapes in the Mediterranean area using a combined multidisciplinary approach: Method and application to Mount Etna (Sicily; Italy). Landscape and Urban Planning, 100: 98-108.

Fish, D., Carpenter, S. L., (1982). Leaf litter and larval mosquito dynamics in tree-hole ecosystems. Ecology, 63: 283-288.

Glaves, P., Rotherham, I.D., Wright, B., Handley, Ch., Birbeck, J., (2009a). Field Surveys for Ancient Woodlands: Issues and Approaches. A Report to the Woodland Trust. Hallam Environmental Consultants Ltd., Biodiversity and Landscape History Research Institute and Geography, Tourism and Environment Change Research Unit, Sheffield Hallam University. Glaves, P., Rotherham, I.D., Wright, B., Handley, Ch., Birbeck, J., (2009b). The identification of ancient woodland: demonstrating antiquity and continuity- issues and approaches. A Report to the Woodland Trust. Hallam Environmental Consultants Ltd., Biodiversity and Landscape History Research Institute and Geography, Tourism and Environment Change Research Unit, Sheffield Hallam University.

Kadavý, J., Kneifl, M., Servus, M., Knott, R., Hurt, V., Flora, M., (2011). Coppice and coppice with standards forests - adequate forest management alternative for small and 
middle forest owners - general starting points. Lesnická práce, Kostelec nad Černými lesy.

Kitching, R.L., (2000). Food webs and container habitats. The natural history and ecology of phytotelmata. Cambridge University Press, UK, 431 pp.

Kitching, R.L., (1971). An ecological study of water-filled tree-holes and their position in the woodland ecosystem. Journal of Animal Ecology, 40: 281-302.

Kraus, D., Bütler, R., Krumm, F., Lachat, T., Larrieu, L., Mergner, U., Paillet, Y., Rydkvist, T., Schuck, A., Winter, S., (2016). Catalogue of tree microhabitats - Reference field list Integrate+ Technical Paper, 16pp.

Kuličková, B., (2016). Hodnocení pařezové výmladnosti v městských lesích Moravský Krumlov (in Czech). Bachelor thessis, Mendel University, Brno.

Larrieu, L., Cabannettes, A., Lachat, T., Paillet, Y., Winter, S., Bouget, C., Deconchat, M., (2014). Deadwood and tree microhabitat dynamics in unharvested temperate mountain mixed forests : a life-cycle approach to biodiversity monitoring. Forest Ecology and Management, 334: 163-173.

Larrieu, L., Cabannettes, A., Delarue, A., (2012). Species, live status, and diameter are important tree features for diversity and abundance of tree microhabitats in subnatural montane beech-fir forests. Canadian Journal of Forest Research, 42: 1433-1445.

Maděra, P., Kovář, P., Romportl, D., Buček, A., Lacina, J., Kučera, A., Holík, L., Dundek, P., Marosz, K., Mikita, T., Klimánek, M., Řepka, R., Hrubý, Z., Koutecký, T., Šebesta, J., Volařík, D., Úradníček, L., Šenfeldr, M., Dreslerová, J., Friedl, M., Černušáková, L., Hamanová, M., Klvač, P., Machala, M., Honzová, M., Boček, S., Matula, R., Pákozdiová, M., Vojta, J., Veselý, A., Wiesner, P., Drhovská, L., Klárová, M., Chuman, T., Rákosníková, A., Čermák, J., Ružbatský, V., Šantrůčková, M., Havlíček, M., Skokanová, H., Fanta, V., Trnka, F., Brestovanský, J., Pech, P., Poubová, A., Stejskal, R., (2014). Czech villages in Romanian Banat: landscape, nature, and culture. Mendelova univerzita v Brně, Brno, 348 pp.

Maděra, P., Machala, M., Slach, T., Friedl, M., Černušáková, L., Volařík, D., Buček, A., (2016). Distribution of ancient coppice woodlands in the Czech Republic. iForest-Biogeosciences and Forestry, submitted.

Matula, R., Svátek, M., Kůrová, J., Úradníček, L., Kadavý, J., Kneifl, M., (2012). The sprouting ability of the main tree species in Central European coppices: implications for coppice restoration. European Journal of Forest Research, 131: 1501-1511.

Mitchell, P.L., (1989). Repollarding large neglected pollards: A review of current practice and results. Arboricultural Journal, 13 (2): 125-142.

Mölder, A., Schmidt, M., Engel, F., Schönfelder, E., Schulz, F., (2015). Bryophytes as indicators of ancient woodlands in Schleswig-Holstein (Northern Germany). Ecological Indicators, 54: 12 30.

Müllerová, J., Szabo, P., Hédl, R., (2014). The rise and fall of traditional forest management in southern Moravia: A history of the past 700 years. Forest Ecology and Management, 331: 104115.

Ouin, A., Cabanettes, A., Andrieu, E., Deconchat, M., Roume, A., Vigan, M., Larrieu, L., (2015). Comparison of tree microhabitats abundance and diversity in the edges and interior of small temperate woodlands. Forest Ecology and Management, 340: 31-39.

Paradise, C.J., Dunson, W.A., (1997). Effects of dissolved water cations on tree-hole insect communities. Annals Entomological Society of America, 90: 798-805.

Pigott, C.D., (1989). Factors controlling the distribution of Tilia cordata Mill at the northern limits of its geographical range. IV. Estimated age of the trees. New Phytologist, 112: 117-121.

Pyttel, P.L., Fischer, U.F., Suchomel, Ch., Gärtner, S.M., Bauhus, J., (2013). The effect of harvesting on stump mortality and re-sprouting in aged oak coppice forests. Forest Ecology and 
Maděra, P., Slach, T., Úradníček, L., Lacina, J., Černušáková, L., Friedl, M., Řepka, R., Buček, A.: Tree shape and form in ancient coppice woodlands

Management, 289: 18-27.

Rackham, O., (1986). The History of the Countryside: The Full Fascinating Story of Britain's Landscape. JM Dent and Sons, London.

Rackham, O., (2003). Ancient woodland, its history, vegetation and uses in England. Castlepoint Press Colvend, Dalbeattie, Kirkcudbrightshire.

Rackham, O., (2008). Ancient woodlands: modern threats. New Phytologist, 180: 571-586.

Read, H., (2000). Veteran trees. A guide to good management. English Nature, 176 pp.

Read, H., (2006). A Brief Review of Pollards and Pollarding in Europe. 1er colloque europeen sur les trognes, Vendome.

Regnery, B., Couvet, D., Kubarek, L., Julien, J.F., Kerbiriou, C., (2013a). Tree microhabitats as indicators of bird and bat communities in Mediterranean forests. Ecological Indicators, 34: 221-230.

Regnery, B., Paillet, Y., Couvet, D., Kerbiriou, C., (2013b). Which factors influence the occurrence and density of tree microhabitats in Mediterranean oak forests ? Forest Ecology and Management, 295: 118-125.

Remm, J., Lõhmus, A., (2011). Tree cavities in forests - The broad distribution pattern of a keystone structure for biodiversity. Forest Ecology and Management, 262: 579-585.

Röhnert, U. (1950): Wassererfüllte Baumhöhlen und ihre Besiedlung. Ein Beitrag zur Fauna dendrolimnetica. Archiev für Hydrobiologie, 44: 475-516.

Rozas, V., (2004). A dendroecological reconstruction of age structure and past management in an old-growth pollarded parkland in northern Spain. Forest Ecology and Management, 195: 205219.

Schmidl, J., Sulzer, P., Kitching, R.L., (2008). The insect assemblage in water filled tree-holes in a European temperate deciduous forest: community composition reflects structural, trophic and physicochemical factors. Hydrobiologia, 598: 285-303.

Sjölund, M.J., Jump, A.S., (2013). The benefits and hazards of exploiting vegetative regeneration for forest conservation management in a warming world. Forestry, 86: 503-513.

Stajic, B., Zlatanov, T., Velichkov, I., Dubravac, T., Trajkov, P., (2009). Past and recent coppice forest management in some regions of South Eastern Europe. Silva Balcanica, 10: 9-19.

Szabo, P., (2009). Open woodland in Europe in the Mesolithic and in the Middle Ages: Can there be a connection? Forest Ecology and Management, 257: 2327-2330.

Szabó, P., Müllerová, J., Suchánková, S., Kotačka, M., (2015). Intensive woodland management in the Middle Ages: spatial modelling based on archival data. Journal of Historical Geography, 48: $1-10$.

Vrška, T., Janík, D., Pálková, M., Adam, D., Trochta, J., (2016). Below- and above-ground biomass, structure and patterns in ancient lowland coppices. iForest-Biogeosciences and Forestry, in press. DOI 10.3832/ifor1839-009.

Vuidot, A., Paillet, Y., Archaux, F., Gosselin, F., (2011). Influence of tree characteristics and forest management on tree microhabitats. Biological Conservation, 144: 441-450.

Winter, S., Möller, G., (2008). Microhabitats in lowland beech forests as monitoring tool for nature conservation. Forest Ecology and Management, 255: 1251-1261.

Yee, D.A., Juliano, S.A., (2006). Consequences of detritus type in an aquatic microsystem: effects on water quality, micro-organisms and performance of the dominant consumer. Freshwater Biology, 51: 448-459. 